\title{
The Microalgae Aurantiochytrium Sp. Increases Neurogenesis and Improves Spatial Learning and Memory in Senescence-Accelerated Prone 8 Mice
}

Kazunori Sasaki

National Institute of Advanced Industrial Science and Technology https://orcid.org/0000-0002-30506331

Noelia Geribaldi-Doldan

University of Tsukuba

Qingqing Wu

University of Tsukuba

Julie Davies

University of Oxford

Francis G. Szele

University of Oxford

Hiroko Isoda ( $\nabla$ isoda.hiroko.ga@u.tsukuba.ac.jp )

\section{Research}

Keywords: Aurantiochytrium sp, Nutraceuticals, Adult neurogenesis, Neuroprotection, proliferation, SAMP8

Posted Date: August 3rd, 2020

DOl: https://doi.org/10.21203/rs.3.rs-51260/v1

License: (c) (1) This work is licensed under a Creative Commons Attribution 4.0 International License. Read Full License 


\section{Abstract \\ Background}

Much attention has recently focused on nutraceuticals which are widely used to promote health. In particular, nutraceuticals with minimal side effects have been developed for preventing or treating neurological diseases such as Alzheimer's disease (AD). The present study was conducted to investigate the potential effect on neural development and function of the microalgae Aurantiochytrium sp. as a nutraceutical.

\section{Methods}

To test the neuroprotection of ethanol extract of Aurantiochytrium (EEA) and n-Hex layer of EEA (HEEA), amyloid-beta $(A \beta)$-stimulated SH-SY5Y cells was used for in vitro AD model. We then assessed the enhancement of neurogenesis of EEA and HEEA using murine ex vivo neurospheres. We also administered EEA or HEEA to SAMP8 mice, a non-transgenic strain with accelerated aging and Alzheimer's-like memory loss for evaluation of spatial learning and memory using MWM test. Finally, we performed immunohistochemical analysis using mice brain fed with EEA for assessment of neurogenesis.

\section{Results}

Pre-treatment of SH-SY5Y cells with EEA or the squalene-rich fraction of EEA, n-Hex layer (HEEA), ameliorated $A \beta$-induced cytotoxicity. Interestingly, only EEA-treated cells showed a significant increase in cell metabolism and intracellular ATP production. Moreover, EEA treatment significantly increased the number of neurospheres, whilst HEEA treatment significantly increased the number of $\beta$-III-tubulin + young neurons and GFAP + astrocytes. SAMP8 mice were given $50 \mathrm{mg} / \mathrm{kg}$ EEA or HEEA orally for 30 days. Learning ability was assessed in the Morris water maze test. EEA and HEEA decreased escape latency time in SAMP8 mice, indicating improved memory. To detect activated stem cells and newborn neurons, we administered BrdU for 9 days and measured BrdU + cells in the dentate gyrus, a neurogenic stem cell niche of the hippocampus. In SAMP8 mice, EEA rapidly and significantly increased the number of BrdU + $\mathrm{GFAP}+$ stem cells as well as their progeny, $\mathrm{BrdU}+\mathrm{NeuN}+$ mature neurons.

\section{Conclusions}

Our data in aggregate indicate that EEA and its constituents could be developed into a nutraceutical for promoting brain health and function against some age-related diseases including neurodegenerative desease, particularly AD. 


\section{Background}

Alzheimer's disease (AD), as a growing world-wide health problem, is the most common and feared form of dementia representing circa $70 \%$ of all dementia cases. Up to now, fundamental therapy for $A D$ have not been established, and it is under difficult circumstances. However, the number of patients with neurodegenerative diseases such as $A D$ has been increasing year by year, therefore, it has been growing interest to the potential of natural products such as nutraceuticals for the treatment or prevention of $A D$.

It is estimated that about 72,500 algal species have been described world-wide [1]. Algae produce a variety of bioactive secondary metabolites that include polyphenolic compounds, polysaccharides, steroids, fatty acids, carotenoids, mycosporine-like amino acids, halogenated compounds, polyketides, lectins, peptides and their derivatives [2,3]. There is growing interest in exploring metabolites from algae, and attention has focused on exploring novel bioactive compounds with the potential for future therapeutic use [4]. A large number of biological functions have been found for algal natural products. They can have anti-oxidant, anti-inflammatory, anti-cancer, immunomodulatory, anti-diabetic, antimicrobial, anti-viral, anti-coagulant, tyrosinase inhibition and UV-protective effects [4].

Aurantiochytrium is an oleaginous microorganism in the Thraustochytriaceae family that has attracted attention because of its ability to produce high levels of polyunsaturated fatty acids and squalene. A research group at the University of Tsukuba found a high squalene-producing (198 mg/g) strain, 18W13a, of Aurantiochytrium sp. from among 150 strains of thraustochytrids isolated in the Okinawa prefecture of Japan [5]. Squalene is a biosynthesized triterpene hydrocarbon and a precursor for all steroids in animals and plants. Squalene is used in the pharmaceutical and medical industries because it increases cellular and non-specific immune functions, decreases serum cholesterol levels, protects against gamma rays and suppresses tumor proliferation [5-8]. Thus, Aurantiochytrium sp. may be useful in the search for new medicines and is considered to have great potential as a renewable source of chemical products, with squalene being of major interest. There have been few reports exploring the physiological effects of Aurantiochytrium sp. However, recent studies demonstrated that an ethanol extract obtained from Aurantiochytrium sp (EEA) had anti-inflammatory effects on RAW264.7 cells [9]. Moreover, EEA also showed an anti-depressant-like effect via anti-inflammation [10]. However, the effects of Aurantiochytrium sp. on central nervous system activity such as learning and memory or adult neurogenesis are unknown.

Senescence-accelerated-prone mice 8 (SAMP8) are a good animal model for age-associated diseases, like $A D[11,12]$. They exhibit deterioration in memory and learning accompanied by CNS inflammation, vascular impairment, gliosis, increased oxidative stress, $A \beta$ accumulation and Tau hyperphosphorylation $[11,13]$. We previously showed that SAMP8 mice given the polyphenol 3,4,5-tricaffeoylquinic acid exhibited increased neurogenesis [14]. In physiologic conditions, neurogenesis occurs in the adult brain in two principal regions, the subgranular zone (SGZ) of the hippocampus $[15,16]$ and the lateral wall of the lateral ventricles, the subventricular zone (SVZ) [17]. 
Thus in the present study we aimed to study the effects of EEA on cell viability, ATP production, and neural differentiation in SH-SY5Y human neuroblastoma cells. We performed complementary in vitro murine neurosphere assays to determine the effects of EEA on proliferation and differentiation of neural stem cells (NCSs) and neural precursor cells (NPCs). The SGZ has been implicated in learning and memory and therefore we examined learning and memory with the Morris water maze in SAMP8 mice administered EEA. Finally, we studied the effects of EEA on SGZ and SVZ stem cell activation and neurogenesis in vivo.

\section{Methods}

\section{Preparation of ethanol extract of Aurantiochytrium sp. (EEA)}

Dried powders of Aurantiochytrium sp. cells were provided by Professor Makoto Watanabe (Algae Biomass and Energy System R\&D Center, University of Tsukuba, Japan). The algae dried powders were extracted using $99.5 \%$ ethanol $(\mathrm{g} / 10 \mathrm{~mL})$, in the dark, and at room temperature for two weeks, with shaking of the mixture occurring at least once a day. At the end of the procedure, the liquid fraction was collected and filtered through a $0.22 \mu \mathrm{m}$ filter. For both in vitro and in vivo experiments, the EEA liquid fraction was concentrated using a SpeedVac (Thermo Fisher Scientific, Japan) For in vitro experiment, the concentrated EEA was dissolved in serum-free Eagle's minimum essential medium (OPTI-MEM; Gibco, Japan) with sonication and for in vivo experiment, the concentrated $150 \mathrm{mg}$ EEA was dissolved in $10 \mathrm{~mL}$ milliQ water with sonication.

\section{Preparation of $\mathbf{n}$-Hexane layer of EEA using liquid-liquid distribution}

To obtain the extract, Aurantiochytrium sp. 18W-13a strain was extracted as above with $99.5 \%$ EtOH for 2 weeks and the EtOH extract was filtered and evaporated in vacuo. The concentrated EEA $(200 \mathrm{mg})$ was dissolved in $100 \mathrm{~mL}$-Hexane and $100 \mathrm{~mL} 90 \% \mathrm{MeOH}$ was added to the extract. The extract was partitioned between the $90 \% \mathrm{MeOH}$ layer and the n-Hexane layer due to the difference in their solubility. Partitioning the $90 \% \mathrm{MeOH}$ layer and $\mathrm{n}$-Hexane layer was repeated twice with $100 \mathrm{~mL} n$-Hexane. Next the n-Hexane layer containing EEA (HEEA) was concentrated using vacuo, $100 \mathrm{mg}$ of this concentrate was dissolved in $1 \mathrm{~mL}$ of $99.5 \% \mathrm{EtOH}$ and used for in vitro experiments. For animal dosing for the in vivo assay, the HEEA was concentrated and the dried 150 mg HEEA was dissolved in $10 \mathrm{~mL}$ milliQ water with sonication.

\section{Preparation of squalene}

Squalene was purchased from Wako Co, Ltd. (Tokyo, Japan). For in vitro assays, squalene was dissolved in medium and sonicated before use in the experiment, because it was difficult to soluble to medium.

\section{SH-SY5Y cell culture}

The human neuroblastoma SH-SY5Y cell line was purchased from the American Type Culture Collection. SH-SY5Y cells were cultured in a 1:1 (v/v) mixture of Dulbecco's modified Eagle Medium and Ham's F-12 
medium (Gibco, Japan) supplemented with $15 \%$ heat-inactivated fetal bovine serum (Bio West, U.S.A) and $1 \%$ penicillin $(5000 \mu \mathrm{g} / \mathrm{ml})$ - streptomycin $(5000 \mathrm{IU} / \mathrm{ml})$ (PS) (Lonza, Japan) at $37^{\circ} \mathrm{C}$ in a humidified atmosphere of $5 \% \mathrm{CO}_{2}$ in air. SH-SY $5 Y$ cells were cultured in $100-\mathrm{mm}$ petri dishes or 96 -well plates. OPTIMEM was used to culture the cells for the cell viability assay.

\section{MTT assay}

Cell viability and mitochondrial activity were determined using a 3-(4,5-dimethylthiazol-2-yl)-2,5diphenyltetrazolium bromide (MTT) assay to check for effects of EEA $(20 \mu \mathrm{g} / \mathrm{mL})$, HEEA $(20 \mu \mathrm{g} / \mathrm{mL})$, squalene $(50 \mu \mathrm{M})$, and Amyloid- $\beta(A \beta)(15 \mu \mathrm{M})$ on cytotoxicity. SH-SY $5 Y$ cells were seeded at $2 \times 10^{5}$ cells/mL in 96-well plates and incubated for $24 \mathrm{hr}$. After $24 \mathrm{hr}$ incubation, SH-SY5Y cells were treated EEA, HEEA, squalene, or $A \beta$ for $72 \mathrm{hr}$. To evaluate the neuroprotective effects of EEA, HEEA, and squalene against $A \beta$-induced cytotoxicity, SH-SY $5 Y$ cells were pre-treated with $20 \mu \mathrm{g} / \mathrm{mL} E E A, 20 \mu \mathrm{g} / \mathrm{mL}$ HEEA, and $50 \mu \mathrm{M}$ squalene for 10 min before $15 \mu \mathrm{M}$ A $\beta$ treatment. After sample treatment, a solution of $5 \mathrm{mg} / \mathrm{ml}$ MTT dissolved in PBS was added $(10 \mu \mathrm{l} /$ well) and incubated for another $24 \mathrm{hr}$. The resulting MTT formazan was dissolved in $100 \mu \mathrm{l}$ of $10 \%$ SDS (w/v) and the absorbance was measured using a microtiter plate reader (Dainippon Sumitomo Pharma Co., Ltd., Japan).

\section{ATP assay}

The effect of EEA on ATP production of SH-SY5Y cells was determined using a luciferase luminescence assay kit (ATP reagents for cell: TOYO Ink, Tokyo, Japan). SH-SY5Y cells were seeded at $2 \times 10^{5} \mathrm{cells} / \mathrm{mL}$ and incubated for $24 \mathrm{hr}$. After incubation, SH-SY5Y cells were treated with $20 \mu \mathrm{g} / \mathrm{mL}$ EEA. After 6, 12, and $24 \mathrm{hr}$ incubation, the ATP assay reagent was added (100 $\mathrm{\mu l} /$ well) and incubated for $10 \mathrm{~min}$ at room temperature while avoiding light exposure. After the incubation, the solution was transferred into a white clear-bottom 96-well plate (BD Falcon) and the luminescence was detected using a microplate reader (Dainippon Sumitomo Pharma Co., Ltd., Japan).

\section{Primary NPC Culture}

NPCs were obtained from the SVZ of seven-day old postnatal mice following the procedure described by Torrglosa et al., 2007 [18]. Six CD1 mice were used for each independent culture. Neurosphere cultures were maintained in defined medium (DM) composed of Dulbecco's modified Eagle's medium/F12 medium 1:1 (v/v) with $1 \mathrm{mg} / \mathrm{L}$ gentamicin (GIBCO) and B27 supplement (Invitrogen, Carlsbad, CA). EGF (20 ng/mL, GIBCO) and bFGF (10 ng/mL, Peprotech, Frankfurt, Germany) were added to cultures to stimulate cell proliferation and culture expansion. All animal procedures were approved by the Animal Study Committee of Tsukuba University and according to the guidelines for the Care and Use of Animals approved by the Council of the Physiological Society of Japan.

To test the effect of EEA $(20 \mu \mathrm{g} / \mathrm{mL})$ and HEEA $(20 \mu \mathrm{g} / \mathrm{mL})$ on primary neurospheres, single cells from mechanically disaggregated neurospheres were seeded in anti-adherent 96 well plates (Corning, NY, USA) at a density of 20,000 cells $/ \mathrm{mL}$. EEA $(20 \mu \mathrm{g} / \mathrm{mL})$ or HEEA $(20 \mu \mathrm{g} / \mathrm{mL})$, EGF $(20 \mathrm{ng} / \mathrm{mL})$ and bFGF (10 
$\mathrm{ng} / \mathrm{ml}$ ) were added at the time of seeding. $72 \mathrm{hr}$ after seeding, the number of newly formed neurospheres was counted with phase microscopy. To measure neurosphere size, images of at least 50 neurospheres per well were taken. Size was measured using ImageJ softweare. Each treatment was performed in triplicate and repeated at least three independent times.

\section{Immunocytochemistry}

Cells in medium without growth factors were added onto poly-L-ornithine coated 8-well glass slide chambers (Lab-Tek) with EEA. After $72 \mathrm{hr}$, cells were fixed with 4\% (w/v) paraformaldehyde. After 3 washes, cells were incubated with blocking solution composed of phosphate-buffer saline (PBS) containing $2.5 \%(\mathrm{w} / \mathrm{v})$ bovine serum albumin (BSA) for $1 \mathrm{hr}$ to avoid nonspecific antibody binding. Primary antibody incubations were carried out overnight at $4^{\circ} \mathrm{C}$ in blocking solution. Then, cells were washed with PBS and incubated with the appropriate secondary antibody for $1 \mathrm{~h}$.

The primary antibodies used were mouse anti- $\beta$-III-tubulin (Promega, 1:1000) and rabbit anti-GFAP (DAKO, 1:3000). The secondary antibodies used were donkey anti-rabbit Alexa Fluor 488 and donkey anti-mouse 594 (Invitrogen, 1:1000). Nuclei were counterstained with DAPI using drops of ProLong Gold Antifade Mountant (Thermo SCIENTIFIC, Japan). Fluorescence was detected with a Leica DMI 4000B epifluorescent microscope (Leica, Germany). Quantification was performed in 12 predetermined visual fields/well and 3 wells/condition. Experiments were repeated a minimum of 3 times and results were expressed as the mean \pm SEM.

\section{Animals}

Adult male SAMP8 (four-month-old) and SAMR1 (four-month-old) (SLC Japan) were used for in vivo experiments. After acclimatization to laboratory conditions (7 days), SAMP8 mice were divided in three groups, SAMP8 control group, orally administered only with water $(n=6)$, EEA-treated group $(n=7)$, and HEEA-treated group $(n=7)$. SAMR1 mice $(n=10)$ were used as a normal aging control. Animals were housed under controlled conditions of temperature $\left(21-23^{\circ} \mathrm{C}\right)$ and light:dark (12:12 hrs) with free access to food and water. All animal procedures were approved by the Animal Study Committee of Tsukuba University (No.08-007) and according to the guidelines for the Care and Use of Animals approved by the Council of the Physiological Society of Japan.

Oral administration (gavage) of EEA (50 mg/kg) and HEEA (50 mg/ $\mathrm{kg}$ ), dissolved in drinking water, was performed $1 \times$ per day for 30 days. An equal volume of water was administered to the wateradministration group. In addition, $\mathrm{BrdU}(1 \mathrm{mg} / \mathrm{ml})$ was diluted in the drinking water and provided to the SAMR1 control mice, the SAMP8 control group, and the EEA-treated group during 9 consecutive days starting with the 14th day of oral administration.

\section{Morris water maze (MWM)}

Spatial learning and memory were analyzed using the MWM as previously described [14] with minor modifications. A circular pool $(120 \mathrm{~cm}$ in diameter and $45 \mathrm{~cm}$ in height) was filled to a depth of $30 \mathrm{~cm}$ 
with water $\left(23 \pm 2^{\circ} \mathrm{C}\right)$ and was divided into four quadrants. A platform (10 $\mathrm{cm}$ in diameter) was placed in the northeast quadrant and was submerged $1 \mathrm{~cm}$ below the water surface so that it was invisible at water level. Each mouse had daily sessions of one trial for 7 consecutive days. When the mice succeeded, they were allowed to stay for $15 \mathrm{sec}$ on the platform. When mice failed for more than $60 \mathrm{sec}$, the experimenter assisted them to find the platform. A probe trial was performed $24 \mathrm{~h}$ after the last training session of MWM. The platform was removed from the pool in this trial and mice were allowed to swim freely for 60 sec. The number of crossings over the previous position of the platform and the time spent in the target quadrant in which the platform was hidden during the acquisition trials were recorded as measures for spatial memory.

\section{Tissue processing and immunohistochemistry}

Mice were sacrificed by cervical dislocation after the Morris Water Maze (MWM) test, brains were removed and fixed with $4 \%$ PFA for $24 \mathrm{hr}$ at $4^{\circ} \mathrm{C}$. After, brains were cryoprotected in $30 \%$ sucrose $(\mathrm{w} / \mathrm{v})$ in PBS for $48 \mathrm{hr}$ at $4^{\circ} \mathrm{C}$. Serial $30 \mu \mathrm{m}$ coronal brain sections were obtained using a microtome on dry ice. Sections were stored at $-20^{\circ} \mathrm{C}$ in cryoprotectant solution (ethylene glycol, glycerol, $0.1 \mathrm{M}$ phosphate buffer, $\mathrm{pH} 7.4,1: 1: 1: 2$ by volume). Pre-treatment of tissue was required for BrdU detection. BrdU antigen retrieval was achieved with $1 \mathrm{M} \mathrm{HCl}$ at $38.5^{\circ} \mathrm{C}$ for $1 \mathrm{hr}$. Sections were blocked with a solution composed of PBS, $0.1 \%$ Triton X-100 and $1 \%$ bovine serum albumin (Sigma) for $1 \mathrm{hr}$, after washing abundantly with PBS. Primary antibodies were incubated overnight at $4^{\circ} \mathrm{C}$. Sections were washed and incubated with fluorochrome-conjugated specific secondary antibodies overnight at $4^{\circ} \mathrm{C}$. Primary antibodies used were: sheep polyclonal anti-BrdU (1:500, Abcam), rat monoclonal anti-GFAP (1:400, Life Technologies), mouse monoclonal anti-NeuN (1:400, Millipore), goat polyclonal anti-DCX (1:100, Santa Cruz). The secondary antibodies were conjugated to Alexa-488, -568 or -647 (Invitrogen Paisley, Renfrewshire, UK; 1:500). Sections were mounted with Prolong Antifade Kit (Molecular Probes, Eugene, USA). A Leica DMIRB microscope with a Hamamatsu C4742-95 digital camera or a Leica DMR microscope with a Leica DFC500 digital camera was used to obtain epifluorescence images. Confocal images were obtained with a Zeiss LSM 710 laser scanning confocal microscope using the Z-stack and tile functions as appropriate.

\section{Quantification and statistical analysis}

All analysis was performed blind to the condition on coded slides as previously described [19]. Microsoft Excel was used for collating all data and the statistical analysis was performed using SPSS Statistics 22. When more than one treatment group was compared to controls statistical analysis were preformed using one-way ANOVA followed by post-hoc Bonferroni's test. A Student's t test was used when only one group was compared with the controls. Differences was considered significant a denoted with asterisks at values of $* P<0.05$ or $* * P<0.01$.

\section{Results}

EEA, HEEA and squalene inhibit A $\beta$-induced cell death and EEA increased ATP production 
SH-SY5Y cells were treated with EEA $(20 \mu \mathrm{g} / \mathrm{mL})$, HEEA $(20 \mu \mathrm{g} / \mathrm{mL})$, or squalene $(20 \mu \mathrm{g} / \mathrm{mL})$ for $72 \mathrm{hr}$ and cell viability measured with the MTT assay. To evaluate the neuroprotective effect of EEA and HEEA, SHSY5Y cells were pre-treated with $20 \mu \mathrm{g} / \mathrm{mL}$ EEA or $20 \mu \mathrm{g} / \mathrm{mL}$ HEEA for $10 \mathrm{~min}$. And then, A $\beta$ was added (final concentration: $15 \mu \mathrm{M}$ ) and co-treated with EEA or HEEA for $72 \mathrm{hr}$. Then cell viability was measured with the MTT assay. The Aß-treated group showed a significantly reduction in cell viability compared to the non-treated group $(40.9 \pm 1.4 \%)$. In contrast, pre-treatment with $20 \mu \mathrm{g} / \mathrm{mL}$ EEA or $20 \mu \mathrm{g} / \mathrm{mL} H E E A$ ameliorated $A \beta$-induced cytotoxicity $(186.8 \pm 6.9 \%$ and $138.9 \pm 4.2 \%$ compared to $100 \%$ in $A \beta$-treated cells, respectively, $\mathrm{P}<0.01$ ) (Figure $1 \mathrm{~A}$ and $1 \mathrm{~B}$ ). Interestingly, EEA only treated cells showed a significant increase in cell viability compared with non-treated cells (Figure 1A). Moreover, pretreatment with $50 \mu \mathrm{M}$ squalene for $10 \mathrm{~min}$ also reversed $A \beta$-induced cell death, resulting in a significant increase in cell viability (136.0 $\pm 4.0 \%$ compared to $100 \%$ in $A \beta$-treated cells, $P<0.01$ ) (Figure $1 \mathrm{C}$ ).

Because EEA increased cell viability in SH-SY5Y cells (Figure 1A), we considered whether EEA affects intracellular ATP levels. In addition, $A \beta$ is used as an oxidative stress inducer which can decrease intracellular ATP levels by causing dysfunction in mitochondria. We found that $20 \mu \mathrm{g} / \mathrm{mL}$ EEA treatment significantly increased intracellular ATP levels, $112.8 \pm 3.8 \%, 121.5 \pm 3.4 \%$, and $124.9 \pm 2.5 \%$ compared with non-treated cells after 6, 12, and $24 \mathrm{hr}$ incubation, respectively (Figure 1D).

\section{EEA increased the number of neurospheres}

High availability of energy is important for the CNS because neurons require ATP for many critical functions including firing action potentials, survival, proliferation and differentiation in stem cell niches. Based on our results that EEA increased cell viability and ATP production in SH-SY5Y cells, we evaluated the effects of EEA and HEEA on proliferation and differentiation using neurosphere assays. Neurospheres are primary cultures of stem and progenitors cells isolated from neurogenic niches consisting of floating aggregates of cells that can be used to evaluate the effects of molecules on NPCs. The size of neurospheres is indicative of NPC proliferation while neurosphere numbers are indicative of self-renewal and survival. Experiments were performed in the presence of EGF and bFGF in order to stimulate neurosphere formation. Murine neurospheres were treated for $72 \mathrm{hr}$ with $20 \mu \mathrm{g} / \mathrm{mL}$ EEA or $20 \mu \mathrm{g} / \mathrm{mL}$ HEEA. EEA treatment significantly increased the number of neurospheres $(P<0.01)$ but did not modify neurosphere size (Figure 2). These results suggested that EEA treatment increased the self-renewal capacity or survival of NPC but did not induce proliferation. In contrast to EEA, HEEA treatment did not modify neurosphere number or neurosphere size (Figure 2B and 2C).

\section{EEA and HEEA had opposite effects on neural differentiation}

In order to study the fate of neurosphere derived-cells treated with EEA and HEEA, we performed immunocytochemistry for the young neuron marker $\beta$-III-tubulin and the astrocytic and stem cell marker GFAP. Cells were seeded onto poly-L-ornithine pre-treated 8-well glass slides and cultured in media containing $20 \mu \mathrm{g} / \mathrm{mL}$ EEA or $20 \mu \mathrm{g} / \mathrm{mL}$ HEEA for $72 \mathrm{hr}$. None of the treatments decreased cell viability (Figure 3B). However, EEA significantly decreased the number of $\beta$-III-tubulin+ cells and also the number of GFAP+ cells compared to controls, suggesting that EEA can preserve the undifferentiated state of these 
cells (Figure 3C and 3D). In contrast, treatment with HEEA increased the number of $\beta$-III-tubulin + and GFAP+ cells compared with the control and with EEA, suggesting that the squalene rich fraction of EEA increased differentiation of these cells (Figure $3 \mathrm{C}$ and $3 \mathrm{D}$ ).

\section{EEA and HEEA improved spatial learning and memory in SAMP8 mice}

To evaluate the effect of EEA and HEEA (squalene-rich fraction of EEA) on spatial learning and memory in SAMP8 mice, the Morris water maze (MWM) test was performed. The MWM is a widely used tool to assess spatial learning and memory in rodents. In the MWM, the animal finds or is placed on a platform concealed under the surface of the water in a pool. The time each mouse takes to subsequently swim to the platform indicates how quickly it can recall the location of the platform. To assess the effect of EEA and HEEA on spatial learning and memory, we measured the swimming time of the mice to reach the platform. As shown in Figure 5A, the escape latency time of EEA-treated SAMP8 mice was significantly decreased compared to water-treated SAMP8 mice from the 6th and 7th day of training. There was no difference in the escape latency between SAMR1 mice and EEA-treated SAMP8 mice. Moreover, HEEAtreated SAMP8 mice also showed a significantly decreased escape latency time compared to watertreated SAMP8 mice at day 7 (Figure 4A).

Figure $4 \mathrm{~B}$ and Figure $4 \mathrm{C}$ show that the time spent in the target quadrant and the number of times the mouse crossed the platform was significantly higher in the EEA-treated SAMP8 group compared to the water-treated SAMP8 group. However, no significant difference was observed in the number of crossings of the target quadrant between the HEEA-treated SAMP8 group and the water-treated SAMP8 group.

\section{EEA activates neural stem cells and neurogenesis in the hippocampus of SAMP8 mice}

To test EEA ( $50 \mathrm{mg} / \mathrm{kg}$ ) effects on neurogenic niches we administered it orally to SAMP8 mice for 30 days. After the MWM test, brains were collected and immunohistochemistry performed. BrdU, which is incorporated into proliferative cells at S-phase of the cell cycle, was provided in the drinking water of animals for 9 consecutive days starting on the 14th day of EEA treatment. We considered that BrdU+ cells that co-express the NSC and astrocytic marker GFAP were activated stem cells in the SGZ. We also colabelled BrdU+ cells with the neuronal marker NeuN and double positive cells were considered to be newborn neurons. We studied the effects of EEA on the anterior dentate gyrus (DG) and the posterior DG separately because the former is associated with spatial memory and the later more with limbic functions [20]. The number of BrdU+GFAP+ cells was significantly increased in both the anterior and the posterior DG of EEA-treated SAMP8 mice compared to water treated SAMP8 mice (Figure 5B and E). In the anterior $D G, E E A$ also significantly increased the number of newborn neurons that had mature BrdU+NeuN+ cells (Figure $5 \mathrm{C}$ ). In the posterior DG, there was a trend towards an increased number of newborn neurons in the EEA treated SAMP8 mice but this did not reach statistical significance (Figure 5F). Our data suggested that EEA augmented stem cell activation and neurogenesis in the hippocampal DG of SAMP8 mice. 
We next asked if EEA affects the other major neurogenic niche, the SVZ. We found that the total number of BrdU+ cells was greater in SAMP8 mice compared to the SAMR1 control mice, independent of treatment (Figure 6A and 6B). However, there were no significant differences in the number of BrdU+ cells that co-express the astrocyte and stem cell marker GFAP (Figure 6C). Nevertheless, SAMP8 EEA-treated mice exhibited a significant increase in the BrdU+ cells that co-express the neuroblast marker DCX in the SVZ compared to SAMP8+water treated mice (Figure 6D and 6E). We used DCX instead of NeuN here because NeuN expression only occurs once SVZ nneuroblass have reached he olfactory bulbs, whereas DCX is expressed in newborn neurons in the SVZ [21]. Together, the data suggest that even though NSCs were not activated in the SVZ, neurogenesis was increased by EEA.

We also performed double-labelling immunohistochemestry for BrdU and DCX in the dentate gyrus (Supplementary figure 1). There was no statistically significant difference between groups in the anterior $D G$, however we observed a clear tendency indicating an increase in the number of BrdU+DCX+cells in EEA-treated SAMP8 mice compared with SAMR1 and SAMP8 water-treated mice (Data not shown). Similar to the anterior DG, there was no statistically significant difference in the posterior DG among the 3 groups (Data not shown).

\section{Discussion}

Over the past few decades, many studies have improved our knowledge of age-related neurodegenerative diseases such as AD. Nevertheless, the development of preventive or therapeutic drugs and functional foods for these diseases is still a difficult task. Nutraceuticals are at the intersection of pharmaceuticals and nutrition and render health or medical benefits including the prevention and treatment of disease. Numerous studies have demonstrated the neuroprotective effects of nutraceuticals against toxic compounds associated with neurodegenerative diseases, via mechanisms such as modulation of energy metabolism, oxidative stress, neuroinflammation as well as promotion of neurogenesis via growth factors and neurotrophins [22, 23]. In particular, the relationship between adult neurogenesis and AD has been debated in recent years $[24,25]$. Previous studies have reported that the reduction of expression of neurogenesis markers in the SVZ and DG regions of post-mortem AD brain. Moreover, several studies demonstrated the increase of neurogenesis in animal models and humanized three-dimensional systems of $A D$ can counteract the pathological outcomes $[26,27,28]$. Therefore, restoring neurogenesis by the increase of NSCs would be worth investigating as a treatment for AD. In this study, we focus on an microalgae Aurantiochytrium as nutraceutical for the treatment of AD. We evaluated ethanol extract of Aurantiochytrium (EEA)'s neuroprotective effect on human neural SH-SY5Y cells, stem cell properties in murine neurosphere primary cultures. Moreover, we also evaluated the effect of EEA on spatial learning and memory and in vivo neurogenesis in SAMP8 mice, a good model for aging related brain dysfunction such as AD.

First of all, the current study aimed to first evaluate ethanol extract of Aurantiochytrium (EEA) for its in vitro cytotoxicity on human SH-SY5Y cells. SH-SY5Y neural cells were selected, as they are used widely for evaluation of neurotoxic, neuroprotective and neuroadaptive properties of various phytoconstituents 
and other chemical entities [29, 30]. In our present study, EEA $(20 \mu \mathrm{g} / \mathrm{mL})$-treated cells significantly increased cell viability of $A \beta$-treated cells. Moreover, the $n$-Hexan layer of EEA (HEEA) and squalene also significantly increased cell viability of $A \beta$-treated cells. $A \beta$, a 39-43 amino acid peptide, is a major component of neuritic plaques and a pathological hallmark of $A D$, along with neurofibrillary tangles. The molecular mechanism that links $A \beta$ to the development of neurotoxicity is poorly understood, but some evidence suggests that it is caused by oxidative stress [31], neuroinflammation [32] and dysfunction of mitochondria [33]. Dysfunction of energy metabolism in the brain occurs during aging but is further exacerbated in neurodegenerative diseases and is considered to be another hallmark of neurodegeneration [34]. Our study showed that treatment of EEA increased cell viability as well as intracellular ATP levels. Therefore, our results suggested that EEA may improve mitochondrial dysfunction induced by $A \beta$ and activate mitochondria.

Metabolic states influence stem cell activation and neurogenesis suggesting EEA could increase these processes [35]. Indeed, we showed that EEA positively affects neurogenesis. We first analyzed the effect of EEA and HEEA in neurosphere cultures. We isolated NCSs and NPCs from the brain and grew neurospheres in proliferation conditions using the growth factors EGF and bFGF to promote neurosphere formation. We measured the number and size of neurospheres, where neurosphere number indirectly indicates the number of cells that enter the cell cycle or their self-renewal capacity $[36,37]$ and size indicates the rate of proliferation [18]. We found that EEA significantly increased the number of neurospheres but not their size, suggesting an increase in this stem cell property of self-renewal upon exposed to EEA. Not only NSCs but also transit-amplifying progenitor cells can form new neurospheres, and some data suggest quiescent stem cells are not detected in neurospheres [38]. Thus, EEA may have had an effect on multiple different cells in our cultures. In contrast to EEA, we found that HEEA did not affect neurosphere proliferation or self-renewal. We surmise that there were constituents in EEA that induced these effects but that were absent from the HEEA, hexane purified EEA.

We subsequently found additional differences in the effects of EEA versus HEEA. In terms of neurosphere differentiation, EEA decreased the number $\beta$-III-tubulin + neurons while HEEA increased it. The same occurred with the number of GFAP + cells. These results suggest that HEEA can induce differentiation of NPC into both neurons or glia while EEA keeps them in an undifferentiated state. Recent studies showed EEA and one of its active components, squalene, have neuroprotective effects, protecting stressed neurons from cell death [10]. Several genes related to chemokine signaling pathways are downregulated in EEA-treated mice and may contribute to anti-inflammatory effects [10]. Squalene, which is concentrated in the HEEA layer, is essential in NSCs and NPC cholesterol biosynthesis. Ablation of squalene synthase promoted apoptosis in newborn neurons and reduced brain size [39]. Also, disruption of cholesterol synthesis affected the radial glia fiber scaffold necessary for the migration of newborn neurons and was related to reduced cell self-renewal [40].

In our previous work, we evaluated the neuroprotective effects of several natural compounds on $A \beta$ treated SH-SY5Y cells, as an in vitro models of AD [41, 42]. Interestingly, this AD model showed a strong correlation with the results of our previous behavioral experiments (MWM) using SAMP8 mice [41, 42]. In 
this study, EEA and HEEA showed neuroprotective effects against A $\beta$-induced toxicity. Therefore, the present study also sought to evaluate the effects of EEA and HEEA treatment in spatial and learning memory in SAMP8, a well-characterized model for studying brain aging and neurodegeneration $[11,12]$. SAMP8 mice show age-related deterioration in learning and memory ability with comprehensive brain pathological changes including $A \beta$ deposition [43] and have been used as a non-transgenic murine model for accelerated senescence and AD [44]. In our study, we found that SAMP8 mice treated with EEA and HEEA demonstrated increased learning ability in the MWM test. Thus, our results suggested that EEA and HEEA may have the potential to restore neuronal damage and death induced by $A \beta$, which may help improve spatial learning and memory in SAMP8 mice.

Using gavage, EEA was administered to SAMP8 and SAMR1 mice to study proliferation in vivo in the neurogenic stem cell niches. The hippocampal SGZ has been shown to mediate learning and memory [45]. In the SGZ, we found significantly more cells that co-express the proliferation marker BrdU and the mature neuronal marker NeuN, indicating that EEA encourages neurogenesis in this region. Additionally, we observed increased numbers of BrdU + cells co-expressing the glial and stem cell marker GFAP in the anterior SGZ. This increase suggests that quiescent NSCs could be activated by EEA, eventually increasing neuronal production. One potential mechanism is related to fatty acid metabolism. EEA could induce de novo lipogenesis, which is key in neurogenesis [46] and so, ameliorate SAMP8 cognitive deficiencies. We also studied the other important neurogenesis niche, the SVZ and found more BrdU + cells that co-express the neuroblast marker DCX in the SVZ of SAMP8 mice treated with EEA. In contrast we found no significant changes but in the BrdU + cells that co-express the glial and neural stem cell marker GFAP, suggesting that EEA induce neurogenesis in the SVZ, but not activation of NSCs.

\section{Conclusion}

Taken together, our present research suggests that Aurantiochytrium improves spatial learning and memory in SAMP8, an animal model of aging. This was accompanied by enhancement of neurogenesis in the hippocampal DG. Our new findings in aggregate suggest that EEA could be used as a new therapeutic agent for the treatment of neurodegenerative diseases or other age-related problems.

\section{Abbreviations}

AD: Alzheimer's Disease; A $\beta$ :Amyloid- $\beta$; EEA:ethanol extract of Aurantiochytrium; DG:dentate gyrus; HEEA:n-Hexane layer of EEA; MWM:Morris water maze; NCSs:neural stem cells NPCs:neural precursor cells; PBS:phosphate-buffer saline; SAMP8:Senescence-accelerated-prone mice 8; SGZ:subgranular zone; SVZ:subventricular zone;

\section{Declarations}

\section{Availability of data and materials}


All data generated or analyzed during this study are included in this published article and its supplementary information files.

\section{Ethics approval and consent to participate}

Written informed consent was obtained from all participants.

\section{Consent for publication}

All authors consented manuscript for publication.

\section{Competing interests}

All other authors declare that they have no competing interests.

\section{Author Contributions}

KS, FGS and HI conceived and designed the experiments; KS, NGD and QW performed the experiments; KS and NGD prepared the figures and tables; KS and NGD analyzed and interpreted the results and wrote the paper; FGS and HI edited and revised the manuscript.

\section{Acknowledgements}

This study was partially supported by the project of Japan Science and Technology Agency (JST) Science and Technology Research Partnership for Sustainable Development (SATREPS).

\section{References}

1. Guiry MD. How many species of algae are there? J Phycol. 2012;48:1057-63.

2. Faulkner DJ. Marine natural products. Nat Prod Rep. 2001;18:1-49.

3. Cardozo KH, Guaratini T, Barros MP, Falcão VR, Tonon AP, Lopes NP, Campos S, Torres MA, Souza AO, Colepicolo P, Ernani, Pinto, Pinto E. Metabolites from algae with economical impact. Comp Biochem Physiol C: Toxicol Pharmacol. 2007;146:60-78.

4. Blunt JW, Carroll AR, Copp BR, Davis RA, Keyzers RA, Prinsep MR. Marine natural products. Nat Prod Rep. 2017;34:235-94.

5. Kaya K, Nakazawa A, Matsuura H, Honda D, Inouye I, Watanabe MM. Thraustochytrid Aurantiochytrium sp. 18W-13a accummulates high amounts of squalene. Biosci Biotechnol Biochem. 2011;75:2246-8.

6. Aguilera Y, Dorado ME, Prada FA, Martinez JJ, Quesada A, Ruiz-Gutierrez V. The protective role of squalene in alcohol damage in the chick embryo retina. Exp Eye Res. 2005;80:535-43. 
7. Kelly GS. Squalene and its potential clinical uses. Alternative medicine review: a Journal of clinical therapeutic. 1999;4:29-36.

8. Storm HM, Oh SY, Kimler BF, Norton S. Radioprotection of mice by dietary squalene. Lipids. 1993;28:555-9.

9. Takahashi S, Sakamaki M, Ferdousi F, Yoshida M, Demura M, Watanabe MM, Isoda H. Ethanol Extract of Aurantiochytriummangrovei 18W-13a Strain Possesses Anti-inflammatory Effects on Murine Macrophage RAW264 Cells. Front Physiol. 2018;9:1205.

10. Sasaki K, Othman MB, Ferdousi F, Yoshida M, Watanabe M, Tominaga K, Isoda H. Modulation of the neurotransmitter systems through the anti-inflammatory and antidepressant-like effects of squalene from Aurantiochytrium sp. PLoS One. 2019;14:e0218923.

11. Morley JE, Armbrecht HJ, Farr SA, Kumar VB. The senescence accelerated mouse (SAMP8) as a model for oxidative stress and Alzheimer's disease. Biochim Biophys Acta. 2012;1822:650-6.

12. Morley JE, Farr SA, Kumar VB, Armbrecht HJ. The SAMP8 mouse: a model to develop therapeutic interventions for Alzheimer's disease. Curr Pharm Des. 2012;18(8):1123-30.

13. Cheng XR, Zhou WX, Zhang YX. The behavioral, pathological and therapeutic features of the senescence-accelerated mouse prone 8 strain as an Alzheimer's disease animal model. Ageing Res Rev. 2014;13:13-37.

14. Sasaki K, Davies J, Doldán NG, Arao S, Ferdousi F, Szele FG, Isoda H. 3,4,5-Tricaffeoylquinic acid induces adult neurogenesis and improves deficit of learning and memory in aging model senescence-accelerated prone 8 mice. Aging. 2019;11(2):401-22.

15. Altman J, Das GD. Autoradiographic and histological evidence of postnatal hippocampal neurogenesis in rats. J Comp Neurol. 1965;124:319-35.

16. Kempermann G. Why new neurons? Possible functions for adult hippocampal neurogenesis. The Journal of neuroscience: the official journal of the Society for Neuroscience. 2002;22:635-8.

17. Alvarez-Buylla A, Garcia-Verdugo JM. Neurogenesis in adult subventricular zone. The Journal of neuroscience: the official journal of the Society for Neuroscience. 2002;22:629-34.

18. Torroglosa A, Murillo-Carretero M, Romero-Grimaldi C, Matarredona ER, Campos-Caro A, Estrada C. Nitric oxide decreases subventricular zone stem cell proliferation by inhibition of epidermal growth factor receptor and phosphoinositide-3-kinase/Akt pathway. Stem Cells. 2007;25:88-97.

19. Kandasamy M, Rosskopf M, Wagner K, Klein B, Couillard-Despres S, Reitsamer HA, Stephan M, Nguyen HP, Riess O, Bogdahn U, Winkler J, von Hörsten S, Aigner L. Reduction in subventricular zonederived olfactory bulb neurogenesis in a rat model of Huntington's disease is accompanied by striatal invasion of neuroblasts. PloS one. 2015;10:e0116069.

20. Motta-Teixeira LC, Takada SH, Machado-Nils AV, Nogueira MI, Xavier GF. Spatial learning and neurogenesis: Effects of cessation of wheel running and survival of novel neurons by engagement in cognitive tasks. Hippocampus. 2015;26(6):794-803.

21. Brown JP, Couillard-Després S, Cooper-Kuhn CM, Winkler J, Aigner L, Kuhn HG. Transient expression of doublecortin during adult neurogenesis. The Journal of Comparative Neurology. 2003;467:1-10. 
22. Pandareesh MD, Kandikattu HK, Razack S, Amruta N, Choudhari R, Vikram A. Doddapattar P. Nutrition and nutraceuticals in neuroinflammatory and brain metabolic stress: implications for neurodegenerative disorders. CNS Neurological Disorders - Drug Targets. 2018;17:680-8.

23. Dadhania VP, Trivedi PP, Vikram A, Tripathi DN. Nutraceuticals against neurodegeneration: a mechanistic insight. Curr Neuropharmacol. 2016;14:627-40.

24. Moreno-Jiménez EP, Flor-García M, Terreros-Roncal J, Rábano A, Cafini F, Pallas-Bazarra N, Ávila J, Llorens-Martín M. Adult hippocampal neurogenesis is abundant in neurologically healthy subjects and drops sharply in patients with Alzheimer's disease. Nat Med. 2019;25:554-60.

25. Scopa C, Marrocco F, Latina V, Ruggeri F, Corvaglia V, La Regina F, Ammassari-Teule M, Middei S, Amadoro G, Meli G, Scardigli R, Cattaneo A. Impaired adult neurogenesis is an early event in Alzheimer's disease neurodegeneration, mediated by intracellular $A \beta$ oligomers. Cell Death Differentiation. 2020;27:934-48.

26. Bhattarai P, Thomas AK, Cosacak MI, Papadimitriou C, Mashkaryan V, Froc C, Reinhardt S, Kurth T, Dahl A, Zhang Y, Kizil C. IL4/STAT6 signaling activates neural stem cell proliferation and neurogenesis upon Amyloid- $\beta 42$ aggregation in adult zebrafish brain. Cell Rep. 2016;17:941-8.

27. Choi SH, Bylykbashi E, Chatila ZK, Lee SW, Pulli B, Clemenson GD, Kim E, Rompala A, Oram MK, Asselin C, Aronson J, Zhang C, Miller SJ, Lesinski A, Chen JW, Kim DY, van Praag H, Spiegelman BM, Gage FH, Tanzi RE. Combined adult neurogenesis and BDNF mimic exercise effects on cognition in an Alzheimer's mouse model. Science. 2018;7(6406):361. eaan8821.

28. Papadimitriou C, Celikkaya H, Cosacak MI, Mashkaryan V, Bray L, Bhattarai P, Brandt K, Hollak H, Chen X, He S, Antos CL, Lin W, Thomas AK, Dahl A, Kurth T, Friedrichs J, Zhang Y, Freudenberg U, Werner C, Kizil C. 3D culture method for Alzheimer's disease modeling reveals interleukin-4 rescues Abeta42-induced loss of human neural stem cell plasticity. Dev Cell 2018; 46: 85-101, e108.

29. Venkataramana M, Chandra Nayaka S, Anand T, Rajesh R, Aiyaz M, Divakara ST, Murali HS, Prakash HS, Lakshmana Rao PV. Zearalenone inducedtoxicity in SHSY-5Y cells: the role of oxidative stress evidenced by N-acetyl cysteine. Food Chem Toxicol. 2014;65:335-42.

30. Ramkumar M, Rajasankar S, Gobi VV, Dhanalakshmi C, Manivasagam T, Justin Thenmozhi A, Essa MM, Kalandar A, Chidambaram R. Neuroprotective effect of Demethoxycurcumin, a natural derivative of Curcumin on rotenone induced neurotoxicity in SH-SY5Y Neuroblastoma cells. BMC Complementary Alternative Medicine. 2017;17:217.

31. Cimini A, Benedetti E, D'Angelo B, Cristiano L, Falone S, Di Loreto S, Amicarelli F, Cerù MP. Neuronal response of peroxisomal and peroxisome-related proteins to chronic and acute $A \beta$ injury. Curr Alzheimer Res. 2009;6:238-50.

32. Webers A, Heneka MT, Gleeson PA. The role of innate immune responses and neuroinflammation in amyloid accumulation and progression of Alzheimer's disease. Immunol Cell Biol. 2020;98(1):28-41.

33. Mossmann D, Vögtle FN, Taskin AA, Teixeira PF, Ring J, Burkhart JM, Burger N, Pinho CM, Tadic J, Loreth D, Graff C, Metzger F, Sickmann A, Kretz O, Wiedemann N, Zahedi RP, Madeo F, Glaser E, 
Meisinger $C$. Amyloid- $\beta$ peptide induces mitochondrial dysfunction by inhibition of preprotein maturation. Cell Metab. 2014;20(4):662-9.

34. Camandola S, Mattson MP. Brain metabolism in health, aging, and neurodegeneration. EMBO J. 2017;36:1474-92.

35. Llorens-Bobadilla E, Zhao S, Saiz-Castro G, Zwadlo K, Martin-Villalba A. Single-Cell Transcriptomics reveals a population of dormant neural stem cells that become activated upon brain injury. Cell Stem Cell. 2015;17(3):329-40.

36. Reynolds BA, Weiss S. Clonal and population analyses demonstrate that an EGF-responsive mammalian embryonic CNS precursor is a stem cell. Dev Biol. 1996;175:1-13.

37. Reynolds BA, Rietze RL. Neural stem cells and neurospheres-re-evaluating the relationship. Nat Methods. 2005;2:333-6.

38. Pastrana E, Silva-Vargas V, Doetsch F. Eyes wide open: a critical review of sphere-formation as an assay for stem cells. Cell Stem Cell. 2011;8:486-98.

39. Saito K, Dubreuil V, Arai Y, Wilsch-Brauninger M, Schwudke D, Saher G, Miyata T, Breier G, Thiele C, Shevchenko A, Nave KA, Huttner WB. Ablation of cholesterol biosynthesis in neural stem cells increases their VEGF expression and angiogenesis but causes neuron apoptosis. Proc Natl Acad Sci USA. 2009;106:8350-5.

40. Driver AM, Kratz LE, Kelley RI, Stottmann RW. Altered cholesterol biosynthesis causes precocious neurogenesis in the developing mouse forebrain. Neurobiol Dis. 2016;91:69-82.

41. Han J, Miyamae Y, Shigemori H, Isoda H. Neuroprotective effect of 3,5-di-caffeoylquinic acid on SHSY $5 Y$ cells and senescence-accelerated-prone mice 8 through the up-regulation of phosphoglycerate kinase-1. Neuroscience. 2010;169:1039-45.

42. Sasaki K, Han J, Shimozono H, Villareal MO, Isoda H. Caffeoylquinic acid-rich purple sweet potato extract, with or without anthocyanin, imparts neuroprotection and contributes to the improvement of spatial learning and memory of SAMP8 mouse. J Agric Food Chem. 2013;61:5037-45.

43. Akiguchi I, Pallàs M, Budka H, Akiyama H, Ueno M, Han J, Yagi H, Nishikawa T, Chiba Y, Sugiyama H, Takahashi R, Unno K, Higuchi K, Hosokawa M. SAMP8 mice as a neuropathological model of accelerated brain aging and dementia: Toshio Takeda's legacy and future directions. Neuropathology. 2017;37:293-305.

44. Pallàs M. Senescence-accelerated mice P8: a tool to study brain aging and alzheimer's disease in a mouse model. ISRN Cell Biology. 2012; 2012: 1-12.

45. Anacker C, Hen R. Adult Hippocampal Neurogenesis and Cognitive Flexibility - Linking Memory and Mood. Nat Rev Neurosci. 2017;18(6):335-46.

46. Knobloch M, Braun SM, Zurkirchen L, von Schoultz C, Zamboni N, Arauzo-Bravo MJ, Kovacs WJ, Karalay O, Suter U, Machado RA, Roccio M, Lutolf MP, Semenkovich CF, Jessberger S. Metabolic control of adult neural stem cell activity by Fasn-dependent lipogenesis. Nature. 2013;493:226-30.

\section{Figures}



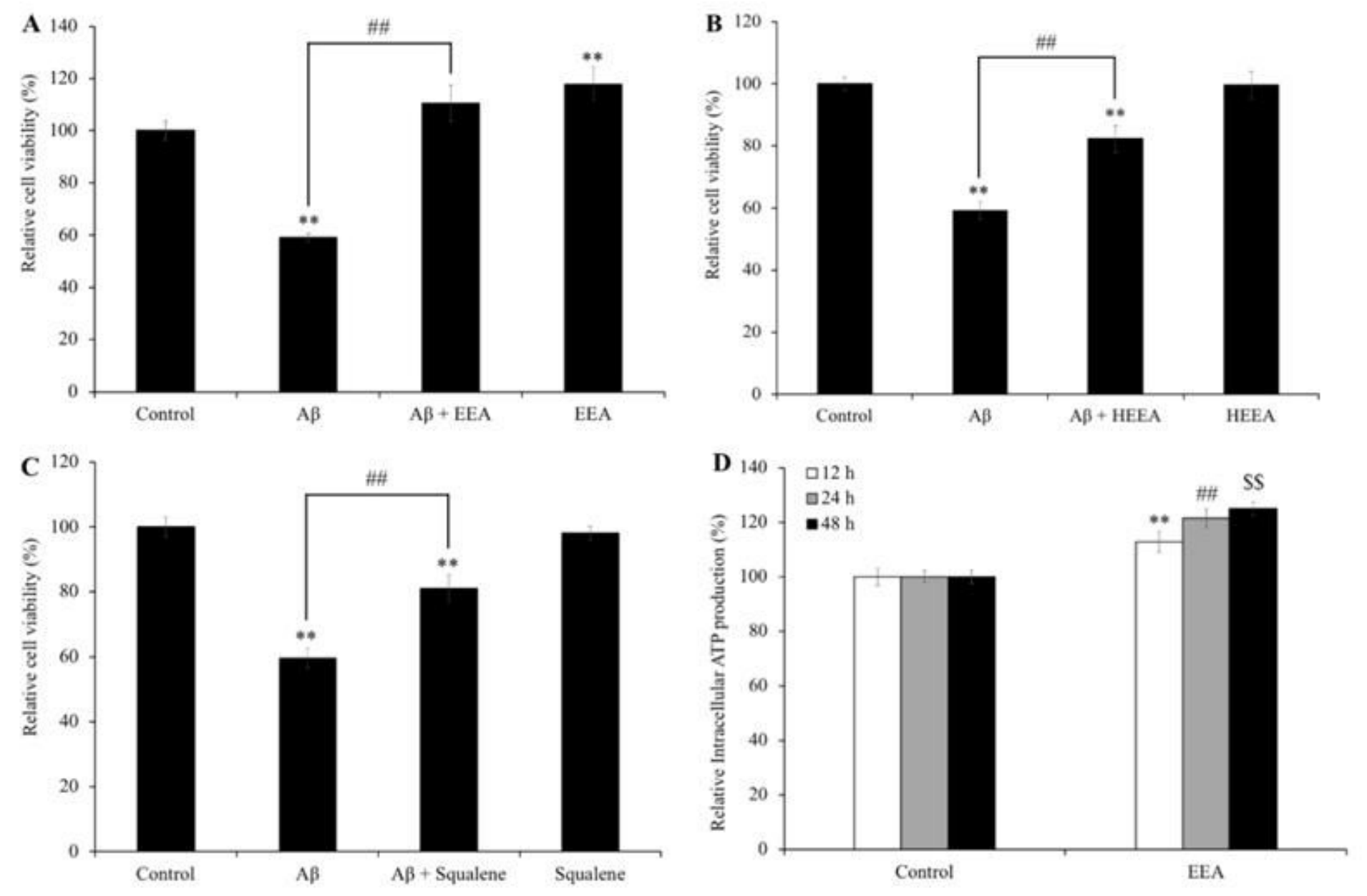

\section{Figure 1}

Effect of (A) ethanol extract of Aurantiochytrium sp. (EEA), (B) Hexane layer of EEA (HEEA), and (C) squalene on the cell viability and Amyloid- $\beta(A \beta)$-induced changes in SH-SY5Y cells viability. (D) Effects of ethanol extract of EEA on ATP production of SH-SY5Y cells. In the MTT assay, the cells were pretreated with EEA $(20 \mu \mathrm{g} / \mathrm{mL})$ or HEEA $(20 \mu \mathrm{g} / \mathrm{mL})$ or squalene $(50 \mu \mathrm{M})$ for $10 \mathrm{~min}$, and then, the cells were treated with $15 \mu \mathrm{M} \mathrm{A \beta}$ for $72 \mathrm{hr}$. And when we perform ATP assay, the cells were treated with EEA (20 $\mu \mathrm{g} / \mathrm{mL}$ ) for 6,12 , and $24 \mathrm{hr}$. After the treatment, intracellular ATP production level was measured. Each bar represents the mean \pm SEM ( $n=5$ independent experiments). ${ }^{*} P<0.01$ vs control cells, \#\# $P<0.01$ vs A $\beta$-treated cells. 
A
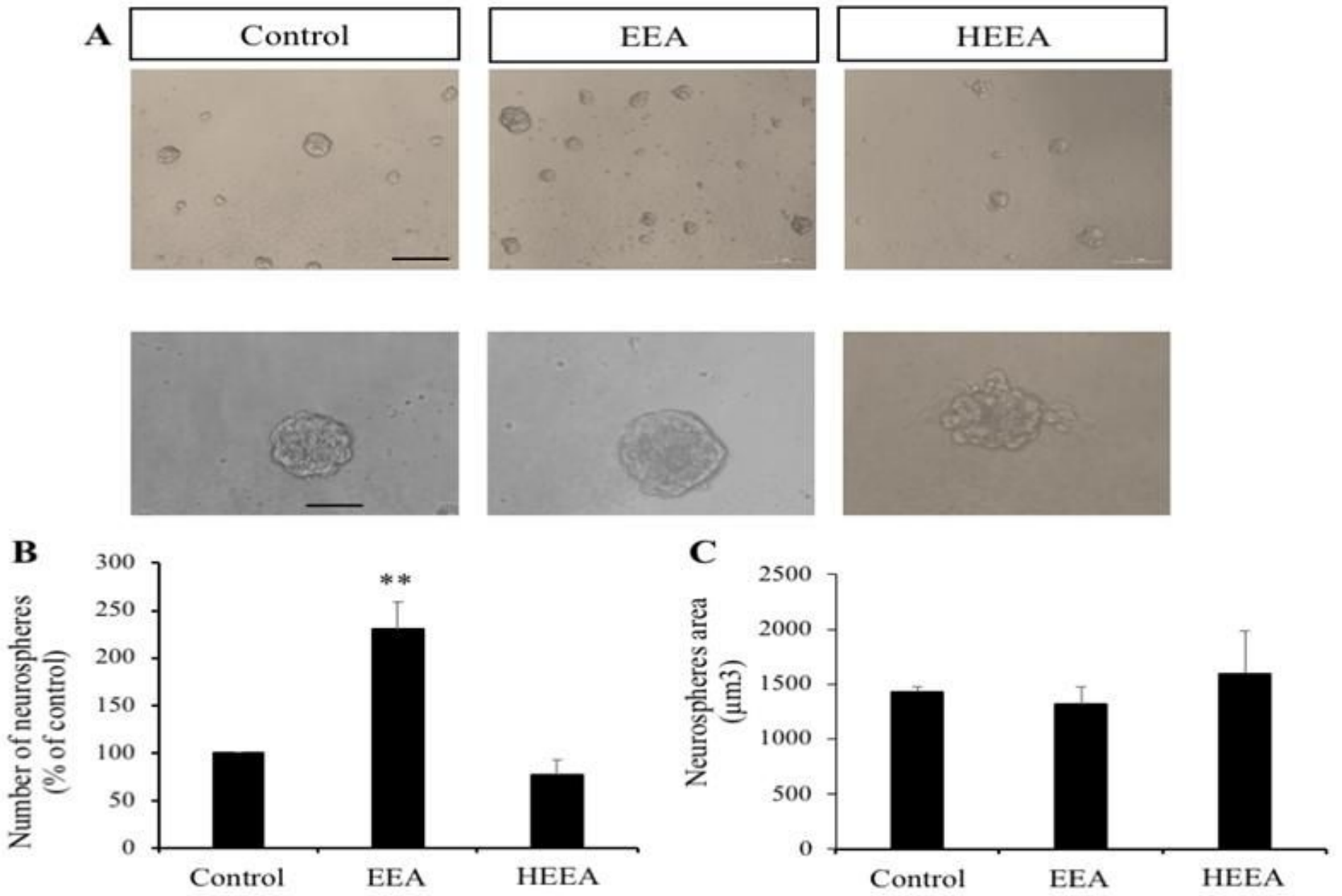

\section{Figure 2}

Effect of ethanol extract of Aurantiochytrium sp. (EEA), and Hexane layer of EEA (HEEA) on NPCs proliferation. Proliferation was tested using neurosphere cultures in presence of EGF $(20 \mathrm{ng} / \mathrm{mL})$ and bFGF (10 ng/mL). (A) Phase contrast microscopy images of neurospheres treated with or without EEA $(20 \mu \mathrm{g} / \mathrm{mL})$ or HEEA $(20 \mu \mathrm{g} / \mathrm{mL})$ during $72 \mathrm{hr}$. Scale bar indicate $100 \mu \mathrm{m}$. (B) Neurosphere number after treatment with grape extract. (C) The size of neurospheres after treatment with EEA or HEEA. ** $P<0.01$ compared with the control in a One-way ANOVA followed by Ryan-Einot-Gabriel-Welsch multiple range test. 
A
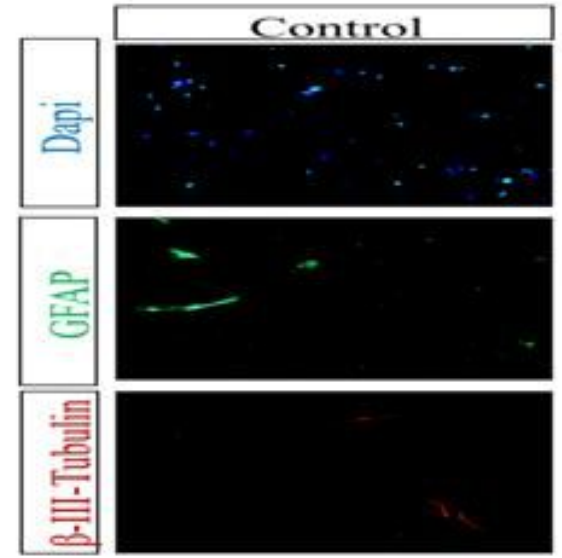

B
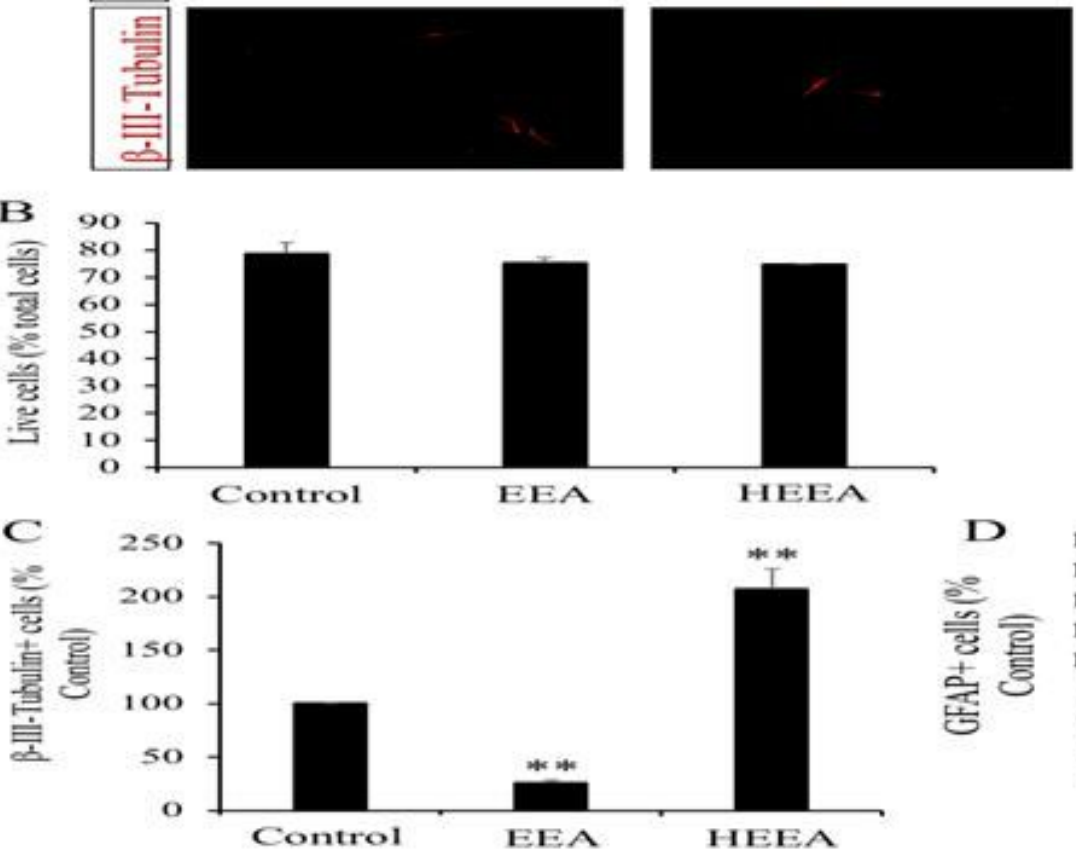
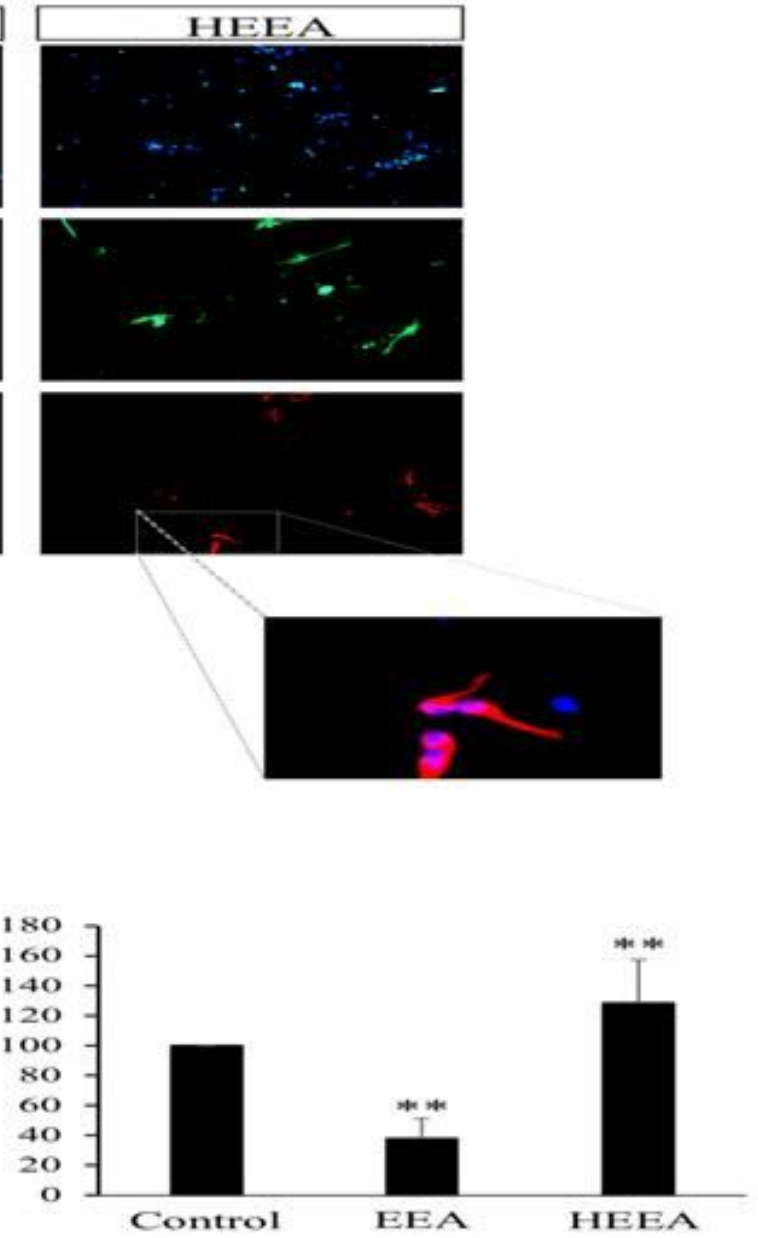

\section{Figure 3}

Effect of ethanol extract of Aurantiochytrium sp. (EEA), and Hexane layer of EEA (HEEA) on NPCs proliferation. Two types of differentiation markers ( $\beta$-III-tubulin for neurons and GFAP for astrocytes) were used. The neurospehres were treated with or without EEA $(20 \mu \mathrm{g} / \mathrm{mL})$ or HEEA $(20 \mu \mathrm{g} / \mathrm{mL})$ during $72 \mathrm{hr}$. (A) Immunofluorescence images demonstrating the expression of $\beta$-III-tubulin and GFAP. (B) The numbers of live cells after EEA or HEEA treatment. (C) The numbers of $\beta$-III-tubulin+ cells after treatment with EEA or HEEA. (D) The numbers of GFAP+ cells after treatment with EEA or HEEA. 


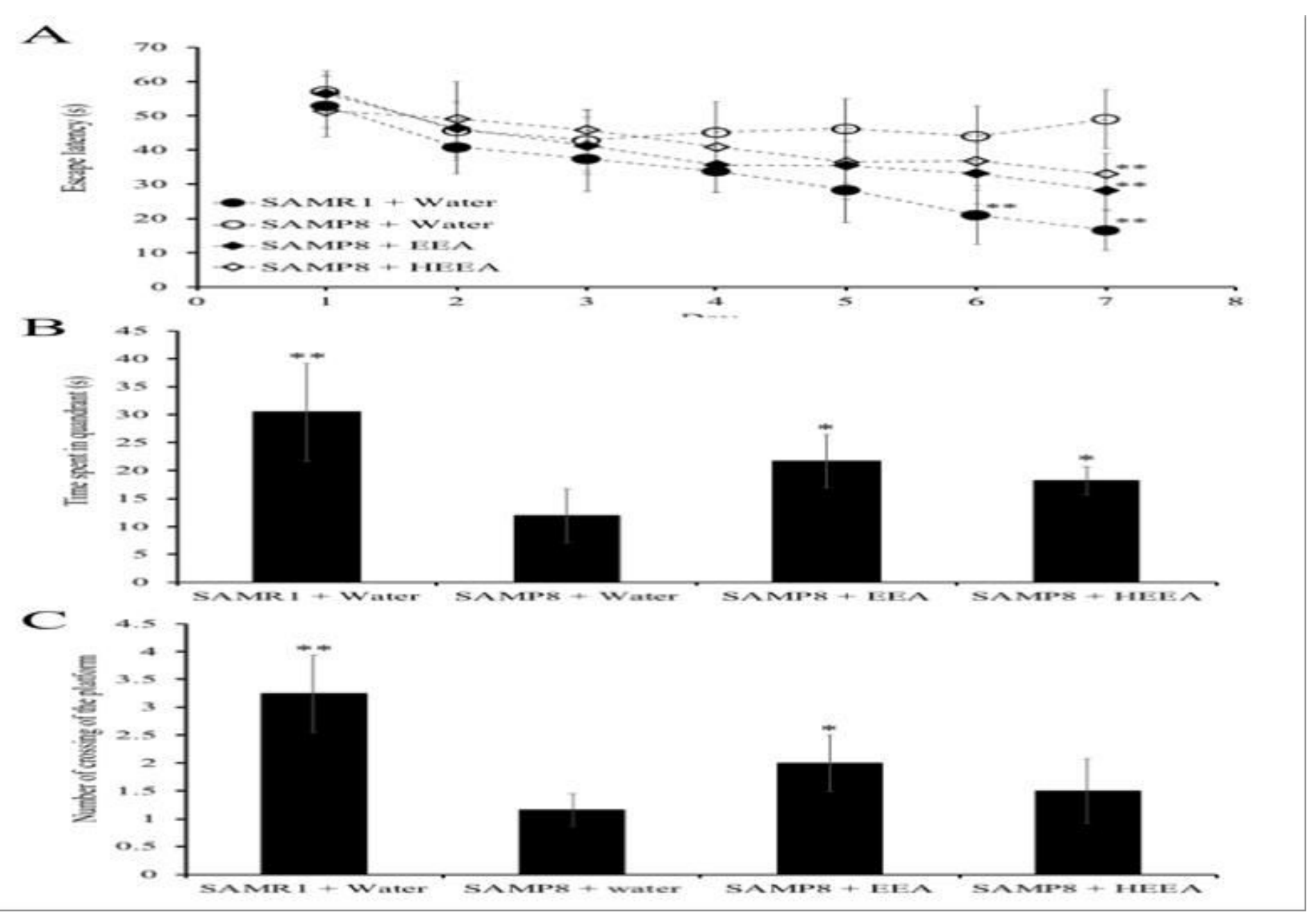

\section{Figure 4}

Effect of ethanol extract of Aurantiochytrium sp. (EEA), and Hexane layer of EEA (HEEA) on the spatial learning and memory as determined by escape latency of senescence-accelerated resistant mouse 1 (SAMR1) mice, senescence-accelerated prone mouse 8 (SAMP8) mice, SAMP8 EEA-treated group, and SAMP8 HEEA-treated group determined by Morris water maze test (A). Effect of EEA or HEEA on the time spent in the target quadrant. (B). Effect of EEA or HEEA on numbers of crossings of platform by SAMR1 untreated and SAMP8 treated or untreated mice $(C)$. ${ }^{*} P<0.05,{ }^{*} P<0.01$ Compared with SAMP8 + water group. 

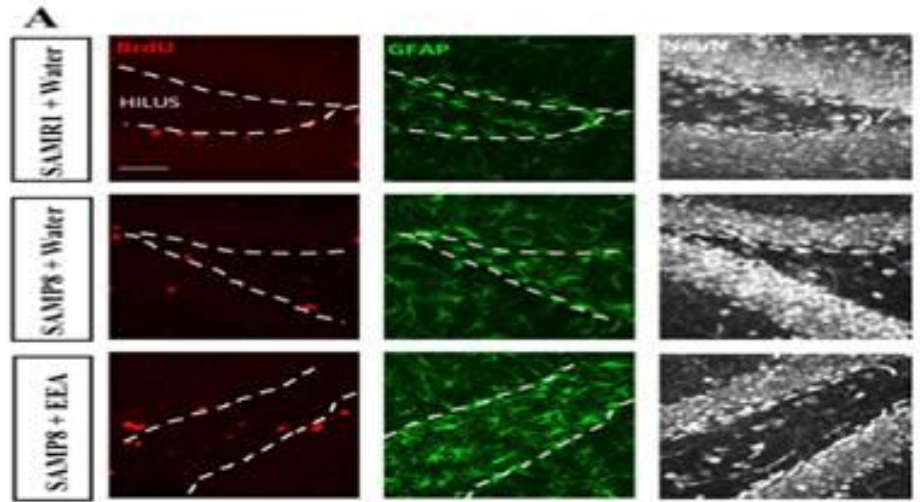

D
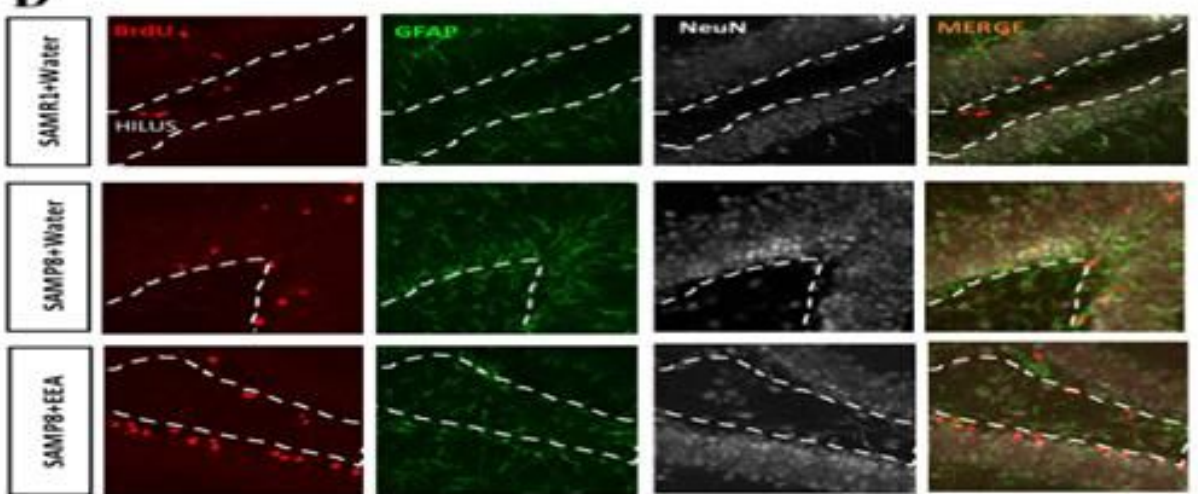
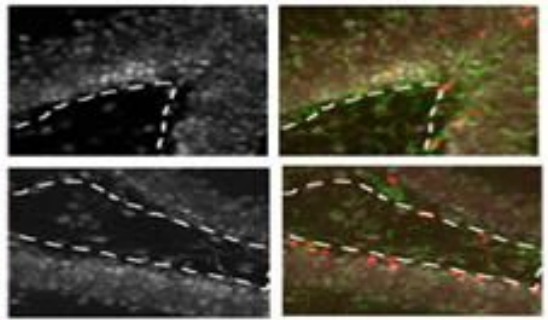
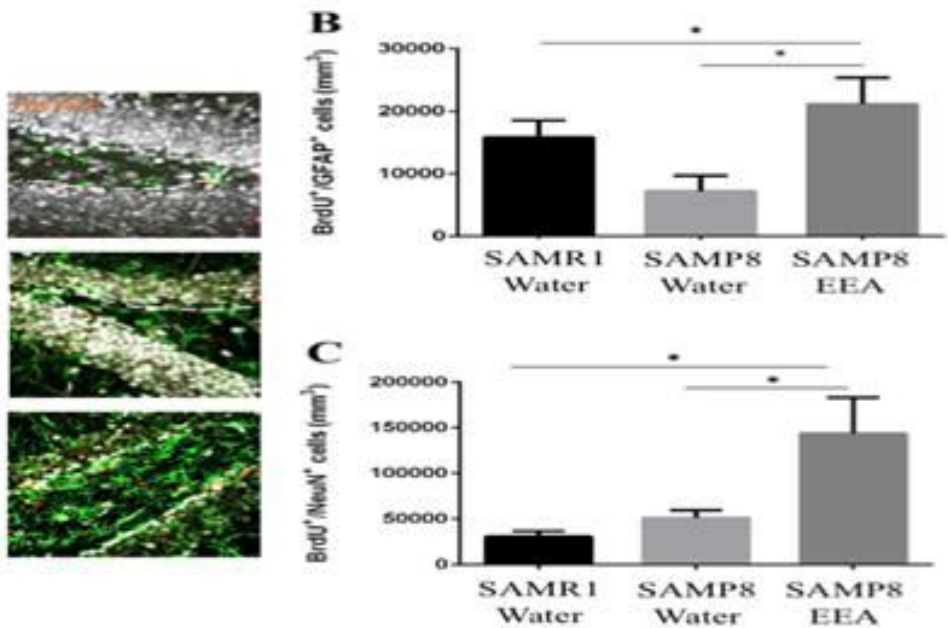

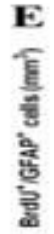
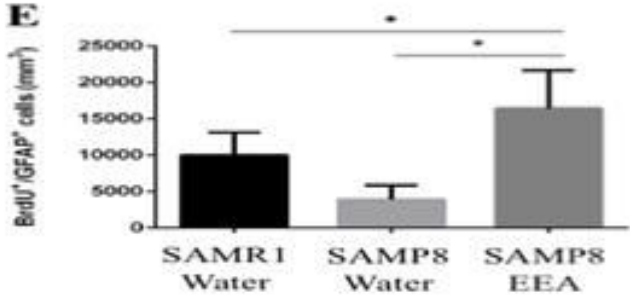

F

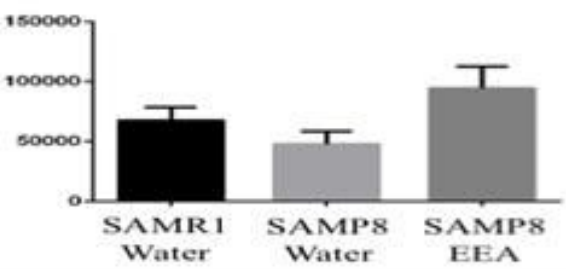

\section{Figure 5}

Effect of oral administration of ethanol extract of Aurantiochytrium sp. (EEA) on anterior and posterior dentate gyrus (DG) stem cell activation and neurogenesis. SAMP8 mice were orally administered with EEA $(50 \mathrm{mg} / \mathrm{kg})$ for 30 days. Photomicrographs show coronal sections containing the anterior $(\mathrm{A})$ and posterior (D) DG processed for immunohistochemical detection of BrdU+ cells (red) and the stem cell marker GFAP (green). The graphs represent the number of BrdU+ cells that co-express the stem cell marker GFAP in the anterior (B) and posterior (E) DG. (C) Graph representing the number of BrdU+ cells that co-express the mature neuronal marker NeuN in the anterior (C) and posterior (F) DG. Each bar represents the mean \pm SEM. ${ }^{*} \mathrm{P}<0.05,{ }^{\star *} \mathrm{P}<0.01$ vs. SAMP8 + water-group. 


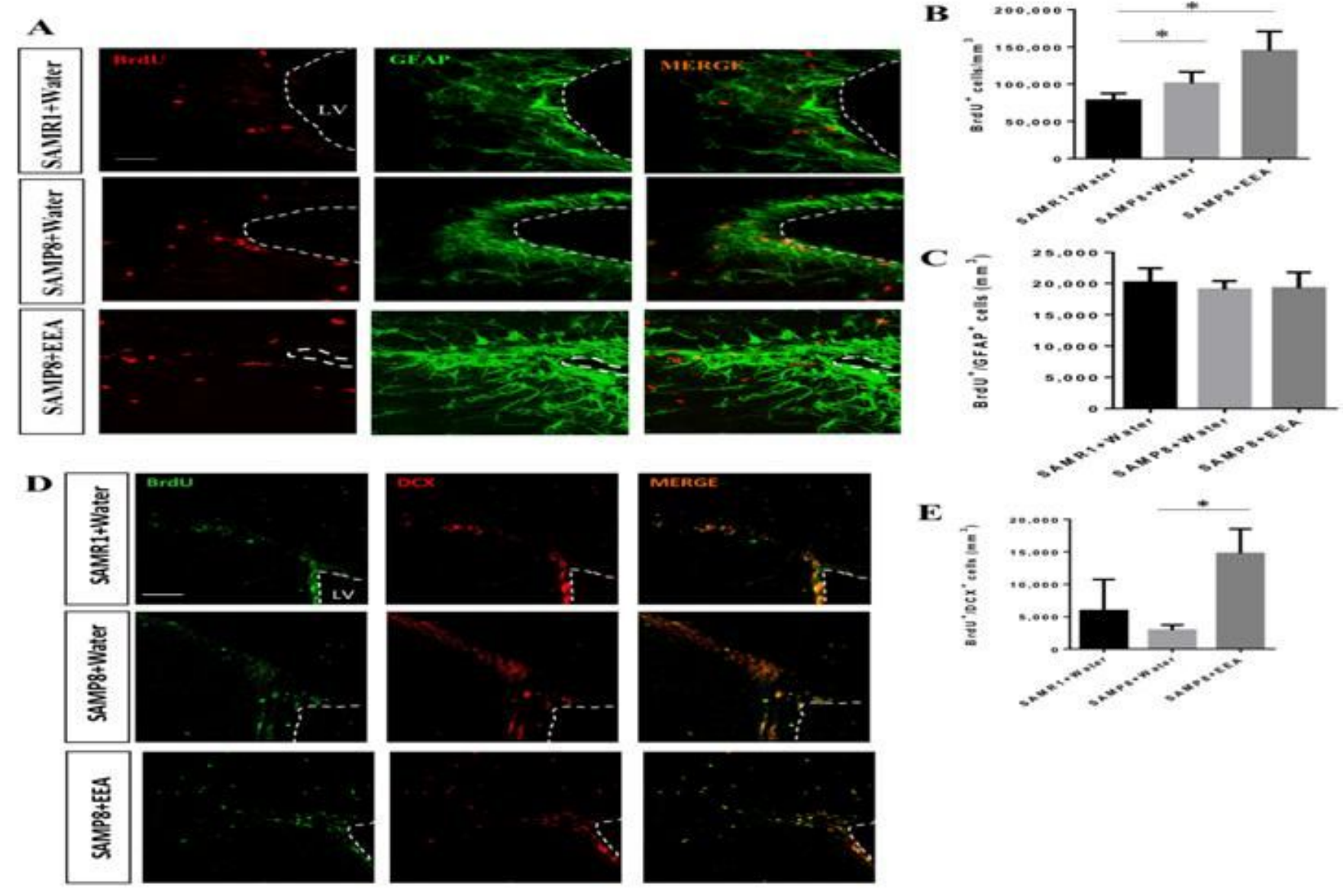

Figure 6

Effect of oral administration of ethanol extract of Aurantiochytrium sp. (EEA) on subventricular zone (SVZ) proliferation. EEA ( $50 \mathrm{mg} / \mathrm{kg}$ ) was orally administered to SAMP8 mice for 30 days (A)

Photomicrograph shows the SVZ in coronal sections processed for immunohistochemical detection of proliferating BrdU+ cells (red) and the astrocyte marker GFAP (green), and (D) BrdU+ cells (green) and the neuroblast marker doublecortin (DCX, red). (B) Graph represents the number of BrdU+ cells in the SVZ. (C) Graph showing the number of BrdU cells that co-express the stem cell and glial marker GFAP. (E) Graph showing the number of BrdU cells that co-express DCX. Each bar represents the mean \pm SEM. ${ }^{*} p<0.05$, ** $P<0.01$ vs. SAMP8 + water-group. 